\title{
幾何条件による自律移動ロボット群の編隊構造遷移
}

\author{
倉 林 大 輔*1 長 川 研 太*2
}

\section{Formation Transition based on Geometrical Features for Multiple Autonomous Mobile Robots}

\author{
Daisuke Kurabayashi*1 $^{* 1}$ and Kenta Osagawa*2
}

\begin{abstract}
In this paper, we propose a formation transition algorithm adapting to geometrical features of an environment for multiple autonomous mobile robots. In order to be compatible both keeping formation and avoiding collisions, we emproyee Delaunay diagram. According to geometrical features that apper in Delaunay diagram, the proposing algorithm determs appropriate neighbors in multiple robots. By adding an algorithm to avoid deadlock situations, the proposing algorithm can guarantee ability that all followers can move with an leader without get lost their ways. We have verified the algorith by carrying out simulations and an experiment.
\end{abstract}

Key Words: Mobile Robots, Formation Control, Distributed Autonomous System

\section{1.は じめに}

近年, 複数自律ロボットの協調作業による作業の効率化が注 目されている。こうした現場において，複数のロボットを同一 の目的地へと移動させることは最も基本的な機能である。この ようなときに，1台のリーダーロボットに指示を与えることで， 他のロボットすべてを確実に目的地まで導くことができれば，指 示・制御の効率化を図ることができる。このために，複数のロ ボットに群れを形成させることが考えられる.

現在, 無人飛行体·無人船舶・無人車両などで同様の考えに 基づき, 群・編隊を形成し移動させる制御アルゴリズムの研究 （例えば文献 $[1] 〜[4] ）$ あるいは群れを組むことによる衝突回避 問題の粒度低下（例えば文献 [5] [6]）が行われている．一般に特 定形状の編隊形成と障害物回避は両立しないため, これらの研 究は自由空間での編隊形成・目標軌道追従制御を主題とするもの と，編隊の定義を緩和し，障害物空間での編隊移動を実現しよ うとするものに大別できる，前者においても，編隊を形成しよ うとするロボット同士の衝突を考慮した研究（例えば文献 [7]） があるが, 複数移動体の目標状態収束問題は P-SPACE 困難ク ラスであることが知られており [8]，ロボット台数の制限や事前 の順位付けといった処理なしでの問題解決は極めてむずかしい. 本研究は後者について扱い, 自律ロボットへ適用可能なアルゴ

\footnotetext{
原稿受付 2004 年 6 月 11 日

*1東京工業大学

*2パイオニア株式会社

${ }^{* 1}$ Tokyo Institute of Technology

${ }^{* 2}$ Pioneer, Inc.
}

リズム構築を目的とする。

障害物空間における群移動アルゴリズムでは, 群れの構造を 陽に考慮するものとそうでないもの，集中管理を前提とするも のと自律制御によるものに区分することができる.

Desai らは，二つの矩形障害物に挟まれた狭領域にノンホロノ ミック移動体からなる群れが進入する際の編隊形状遷移手法 [9] を提案している。ここでは, 適切な編隊形状を組み合わせ探索 により行っており，群を構成するロボット台数に対して計算量 が敏感である，集中管理を行わないと群れ全体の構造を探索す ることができない，といった問題がある.

Shimizu らは，流体力学的相互作用による環境に合わせた形 態制御 [10] 手法を提案している。これによれば，ロボット同士 の仮想的な相互作用によって水の流れに乗るように複数のロボッ トを動作させることができるが，群れの構造について陽に考察 されておらず，群れ分断の有無については保障されていない.

自律移動ロボットには周囲のロボットを見失う可能性が存在 し，特に障害物の存在する環境においてこれは重大な問題であ る. 群れを維持して移動するという作業目標達成のためには， 群れの構造を明確にし，連結状態を保障することが必要である． そのうえで群れとしての停留を回避するため, リアルタイムに 状況に応じた構造の群れになりながら移動を行うことが求めら れる。

本研究では群れの構造を陽に考慮し，構造による群れの性質 を議論する。環境および群内ロボットの相対位置によって一元 的に群れ構造を決定するアルゴリズムを提案し，それを用いて 障害物回避を実現する手法を提案する。シミュレーションと実 験により提案手法の有効性を検証する。 


\section{2. 定式 化}

\section{1 問題設定}

本論文では, 自律ロボットからなる群を以下のように仮定する。

・群は 1 台のリーダーと多数のフォロワから構成される。リー ダーのみに移動目標地点までの目標経路が与えられる。

・ロボットは半径 $R$ の円形で全方向移動可能.

・一定視野 $V$ 内の他ロボット, 障害物の相対位置を計測で き，ロボット・障害物の并別が可能.

・相互情報伝達はできない。

各ロボットについて $V, D, S$ を Fig. 1 のように定義する. $D$ は衝突回避速度成分を発生させる最大距離を表し, これより 遠くの物体は視野内にあっても無視する．S はロボット同士が 離れる限界值で, $S$ 以上隣接ロボットが離れた場合は, その相 手への接近速度ゲインを增大させ, 群れの離散を防ぐ。これら は， $2 R+D<S<V$ を満たすようにあらかじめ決定しておく.

また，フォロワによるリーダー追従を保証するため, リーダー に以下の制限を設ける。

(1) Leader の最大速度は Follower よりも小さい.

(2) 半径 $S$ の内にロボットが1台もいなくなると目標への進行 を中止し，自分もFollower と同じように振る舞う。

ロボットが移動する環境は，矩形および楕円の組み合わせで 表現される障害物が複数存在する二次元平面であるとする.

この環境において,リーダーがすべてのフォロワを目的地ま で連れて行くことを動作目標とする。

\section{2 基本制御式}

本研究では, [6] [11] のようにロボット間・障害物間の距離に 基づく速度成分生成式を設定し, ロボットの移動速度を決定す る。リーダー $L$ およびフォロワ $i に$ 対する速度成分生成式を 式（1），(2) にそれぞれ示す. 式中, 周囲のロボットや障害物 を以下のように記述する。ここで隣接ロボットとは, ロボット $i$ が一定の距離を保つ対象とするロボットを意味し, 次節で詳 細を述べる。

$R O B_{i}: i$ 視野内のロボット集合

$O B S_{i}: i$ 視野内の障害物集合

$O B J_{i}: R O B_{i}$ と $O B S_{i}$ の和集合

$N B R_{i}: i$ の隣接ロボット集合

ここで ${ }^{L} \boldsymbol{g}_{L}$ はリーダーにのみ提示される目標軌道あるいは 目標位置を表す.また ${ }^{i} \boldsymbol{x}_{j}$ は $i$ から見た物体 $j$ の中心座標 $\left({ }^{i} x_{j}{ }^{i} y_{j}\right)^{T}$ を表し, ${ }^{i} \tilde{\boldsymbol{x}}_{j}$ は $i$ における物体 $j$ 上の最近接点座標 を表す. 式 (2) 右辺第 1 項は隣接ロボット方向への速度成分で あり, 第 2 項の反発力とのつりあいにより隣接ロボットと一定 距離内を保ち, 群れを形成する。

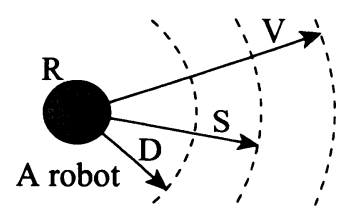

Fig. 1 Parameter settings

$$
\begin{aligned}
&{ }^{L} \dot{\boldsymbol{x}}_{L}= \tau_{L}{ }^{L} \boldsymbol{g}_{L}+\sum_{j \in N B R_{L}} \tau_{L j}{ }^{L} \boldsymbol{x}_{j} \\
&+\sum_{j \in O B J_{L}} \delta_{L j}\left({ }^{L} \tilde{\boldsymbol{x}}_{j}-(R+D) \frac{{ }^{L} \tilde{\boldsymbol{x}}_{j}}{\left|{ }^{L} \tilde{\boldsymbol{x}}_{j}\right|}\right) \\
&{ }^{i} \dot{\boldsymbol{x}}_{i}=\sum_{j \in N B R_{i}} \tau_{i j}{ }^{i} \boldsymbol{x}_{j}+\sum_{j \in O B J_{i}} \delta_{i j}\left({ }^{i} \tilde{\boldsymbol{x}}_{j}-(R+D) \frac{{ }^{i} \tilde{\boldsymbol{x}}_{j}}{\left|{ }^{i} \tilde{\boldsymbol{x}}_{j}\right|}\right)
\end{aligned}
$$

ただし

$$
\begin{gathered}
\tau_{i j}=\left\{\begin{array}{cc}
\tau_{L} & \left(\left|{ }^{i} \boldsymbol{x}_{j}\right| \leq S\right) \\
\tau_{H} & \left({ }^{i} \boldsymbol{x}_{j} \mid>S\right)
\end{array}\right. \\
\left(\tau_{L}<\tau_{H}\right) \\
\delta_{i j}= \begin{cases}\delta & \left({ }^{i} \tilde{\boldsymbol{x}}_{j} \mid \leq R+D\right) \\
0 & \left({ }^{i} \tilde{\boldsymbol{x}}_{j} \mid>R+D\right)\end{cases}
\end{gathered}
$$$$
(\delta>0)
$$

\section{3 群れの構造}

本研究では「群れ」を「一定範囲内の相対位置を保とうとす るロボットの集団」と考える.つまり式 (2) 右辺第 1 項の集合 $N B R_{i}$ の要素への辺に関する和集合がすべてのロボットを要素 に持つことによって群の維持と考える。このことが達成できれ ば，1台のリーダーが他のフォロワを目的地まで連れて行くと いう作業目標が達成できる。

各ロボットを頂点, $\cup_{i=1}^{n} N B R_{i}$ を辺と考えることにより， Fig. 2 のような有向グラフを構成することができる。これを 隣接グラフと呼ぶ. $i$ から $j$ に有向辺が伸びているとき, $j$ が $i$ の隣接ロボットであることを表す．無向辺は，打互いが相手を 隣接ロボットとしていることを表す。隣接グラフによって表さ れる群れ全体の隣接関係を, 群れの構造と呼ぶ.

作業目標達成のためには，隣接グラフが連結であることが必 要条件となる．本論文では，この隣接グラフによる群れ構造を 陽に考慮し, 群れの維持と障害物回避の両立を可能とする動作 アルゴリズムを構築する。

\section{3. 群れ構造の環境適応}

\section{1 望ましい群れ構造}

任意形状の群れ形成と障害物回避は，一般に両立しない。そ こで, 周囲の環境に適応して群れ構造を変化させることが必要 になる。このことを群れの構造遷移と呼ぶ，構造遷移は，(2) における $N B R_{i}$ を変化させることにより行われる.

自由空間移動時には, 群れの維持を優先する. ロボットは視野 が限定されているため隣接ロボットを見失う可能性がある。こ こで隣接グラフが無向 2-辺連結グラフとなっていれば，あるロ ボットが隣接ロボットを 1 台見失っても群れを維持することが

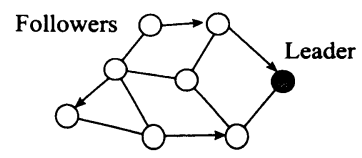

Fig. 2 An example of the formation diagram 
長 川 研 太

できる，一方でロボット同士が密集した群れは衝突の危険性が高 くなるため，隣接グラフを完全グラフあるいはそれに近い形態 とするのも適切ではない. そこで自由空間移動時には Fig. $3(\mathrm{a})$ のように，隣接グラフが幾何学的に自然な無向 2-辺連結グラ フ [12] となるような群れを形成する.このような群れを，「安 定な群れ」と呼ぶ.

一方，ロボット 1 台分しか通れないような狭領域を通過しよ うとする場合，上述の安定な群れを形成したままでは物理的に 環境と干渉してしまう。そこで狭領域通過時には群れの進行を 優先し,Fig. 3(b) のように進行方向に細長い構造をした，「進 行しやすい群れ」を形成する.

本論文では，ドロネー線図により群れと周讲の環境の幾何条 件を表現することで，ロボットと障害物を統一的に扱い，同一 アルゴリズムで環境に適応した群れ構造の決定を可能にするア ルゴリズムを提案する.

\section{2 ドロネー線図による隣接ロボットの決定}

提案するアルゴリズムの流れを Fig. 4 に示す．構造遷移アル ゴリズムは，(1）ある時点（環境）における適切な隣接関係の 決定，(2) 停留回避のための強制的な隣接関係の改変，の二つ からなる。本アルゴリズムにおいて，一定周期毎に呼び出され る「ドロネー線図による隣接ロボットの決定」により（1）が行 われ, 停留時に呼び出される「隣接ロボットの切断」により（2） が実行される.

各ロボットが環境の幾何条件に適応して隣接ロボットを決定 するために，ドロネー線図 [13] を導入する．ドロネー線図とは， 与えられた点 (母点) の集合について，それらの隣接関係を幾何 学的な根拠に基づいて与える代表的な計算幾何処理手法である.

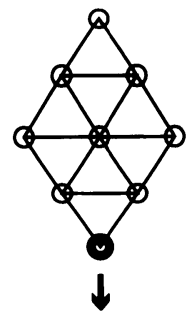

(a) A stable troop

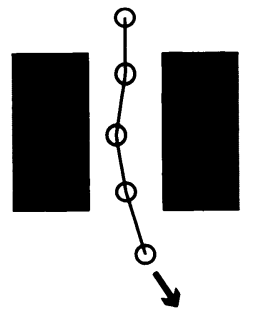

(b) A troop to advance
Fig. 3 Desired formations

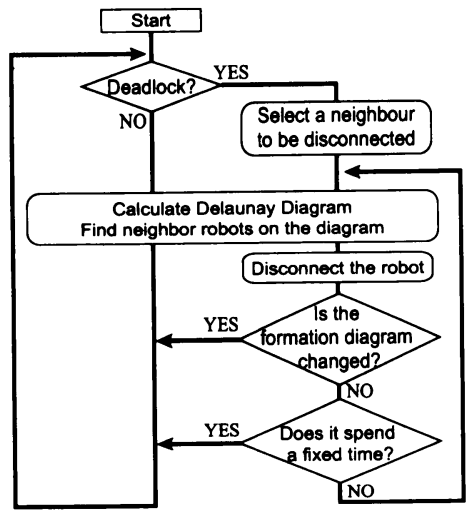

Fig. 4 Flowchart for the formatio transitions
ドロネー線図は，与えられた母点の集合について，外接円 半径を最小化する 3 点の組み合わせを選び，それらを辺で結 んだ図形（三角形の集合）として求められる。あるつの母点 $\left(x_{1}, y_{1}\right),\left(x_{2}, y_{2}\right),\left(x_{3}, y_{3}\right)$ で形成される三角形に対し, 新たな 母点 $\left(x_{4}, y_{4}\right)$ がその外接円内部にある場合 $(3)$ を満たす。この 性質により，ドロネー線図は逐次的に計算することができ，母 点 $n$ 個に対して計算量は $O(n \log n)$ であることが知られ, 自 律型ロボットにとっても十分実用的に計算が可能である.

$$
\left|\begin{array}{llll}
x_{1} & y_{1} & x_{1}^{2}+y_{1}^{2} & 1 \\
x_{2} & y_{2} & x_{2}^{2}+y_{2}^{2} & 1 \\
x_{3} & y_{3} & x_{3}^{2}+y_{3}^{2} & 1 \\
x_{4} & y_{4} & x_{4}^{2}+y_{4}^{2} & 1
\end{array}\right|>1
$$

フォロワは一定周期ごとに，ドロネー線図を元に隣接ロボッ トを決定する。この周期はロボットの駆動制御周期より十分長 くとるものとし，ドロネー生成周期と呼ぶこととする.

Fig. 5 (a) は黒丸で示されたロボットが，白丸で示される視 野内の他のロボットに対して生成した群れ構造を示す。ロボッ ト $i$ の視野内に障害物がなければ $\left(O B S_{i}=\phi\right)$, そのロボット は視野内の他ロボットのみを母点としてドロネー線図を生成す る（Fig. 5(a)）。そうでない場合，Fig. 5(b)のように障害物に 下ろした垂線の足を母点に加え，ドロネー線図を生成した上で， そのロボットと他のロボットを結ぶ辺のみを取り出して隣接グ ラフを構成する．なお, Fig. 5 (b) での点線は, 次節で設計する オフセットを示している.

このアルゴリズムにより，自由空間では隣接グラフが $2-$ 辺連 結グラフとなり，安定な群れを形成する。一方，障害物に挟ま れた狭領域では 2-連結であることは保障されないが，障害物に 沿った進行しやすい群れが形成される.

このアルゴリズムは一般化ボロノイ図が生成可能な幾何形状 の環境であれば実行可能である。本論文では障害物形状を矩形 および円形に限定しているが，仮に扇状の単一障害物が存在し， ロボットがその中心位置にいた場合，障害物に対する垂線の足 を求めることができない。このような点は提案アルゴリズムに おける特異点となる．また，ロボットごとの相対距離計測誤差や ドロネー線図生成タイミングのズレなどによって，ドロネー線 図の形状が相違する可能性がある。これが生じる幾何学的な原 因は，(1）相対距離がほほ等しい母点ペアが複数存在，（2）複

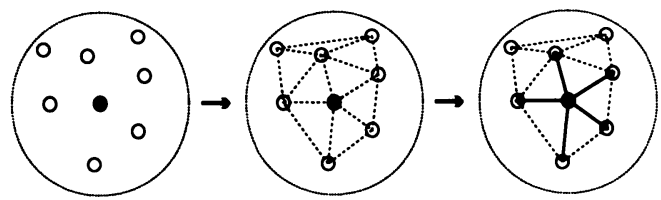

(a) In free space

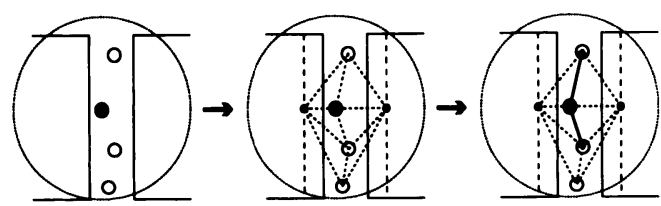

(b) Between obstacles

Fig. 5 Schematic view to generate a diagram 


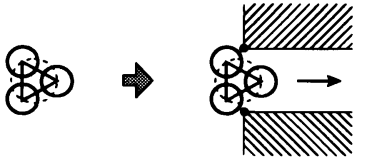

(a) Small size troop

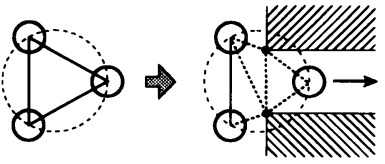

(b) Large size troop
Fig. 6 Disconnection depends on the size of a group

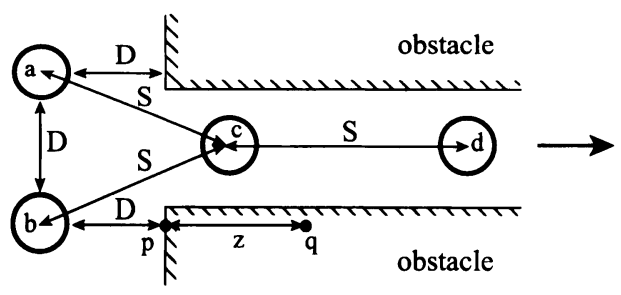

Fig. 7 Additional offset for obstacles

数の母点がごく近距離にある，の 2 通りが考えられる [13]. 前 者の場合，実際にロボットごとにドロネー線図が異なる可能性 があるが，ドロネー線図の外側包絡線（自由空間では凸包）は 変化せず，この部分の連結は保証される，後者は，本論文で扱 うロボットは大きさを持ち，なおかつ反発力により一定距離を 持って安定するため, 影響はないと考えられる.

\section{3 オフセット付与}

ドロネー線図による隣接関係の決定を行う場合，群れにおけ るロボット間距離と環境形状によって，意図せず群れが分断さ れてしまうことがある.Fig. 6 (a) にロボット間距離が狭い群 れ, Fig. 6 (b) に広い群れが狭領域に進入する場合の模式図を示 す. 円がロボットを，円を結ぶ実線が隣接グラフを表す．図のロ ボット 3 台が群れを組み続けるためには，3 台を頂点とする三 角形の外接円内に障害物による母点が，群れの中心軸の上下両 方に存在してはならない. Fig. 6 (a) では破線で示す外接円が十 分小さいため, 狭領域に侵入しても障害物との最近接点（頂点） が円内に入ることはない。一方，Fig. 6 (b) ではロボット間距離 が大きいため, 狭領域進入時に障害物頂点が円内に入り，これ らとのドロネー線図が図中点線のように変化するため，隣接グ ラフが実線部分しか残らず，群れが離れてしまう。

群れの間隔は事前に設計される值であることから，障害物と の距離計算に一定のオフセット $z$ を与えることでこの事象を回 避する． $z$ は以下のように設計する。障害物近傍で進行方向に 群れが十分引っ張られると，近似的に Fig. 7のような状態にな る。このとき $\mathrm{b} に は, \mathrm{c}$ を隣接ロボットとし $\mathrm{d}$ を隣接ロボット としないことが要求され，そのためには，三角形 $\mathrm{abc}$ の外接円 の内部に q が含まれないこと，および三角形 bcd の外接円の内 部に q が含まれることが必要である。これを満たす十分条件と して $z$ を式（4）のように設計する.

$$
\begin{aligned}
& \sqrt{S^{2}-\left(\frac{D+2 R}{2}\right)^{2}}-(D+R)<z \\
& <\sqrt{S^{2}-\left(\frac{D+2 R}{2}\right)^{2}}-(D+R)+S
\end{aligned}
$$

\section{4 隣接関係の切断}

前節の群れ構造決定手法により, 自由空間では安定な群れが,

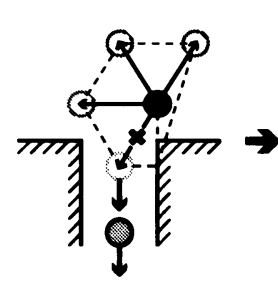

(a) Deadlocked, Disconnection

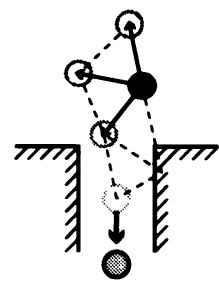

(b) Formation changed

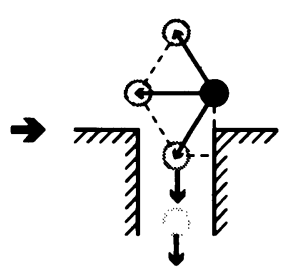

(c) Proceeded one step
Fig. 8 Trial disconnections

狭領域内では進行しやすい群れが自律的に形成される。ここで 前者から後者へと構造遷移を起こすためには， ロボットが狭領 域内へ入り込む必要がある。しかし障害物形状がスムーズな曲 線でない場合はこのことが保証されず，構造遷移が起きずに停 留してしまう可能性がある。そこで停留時において構造遷移を 保証するため, 隣接関係の切断を行うアルゴリズムを導入する. これは, 遷移すべき群れ構造の一部をランダム探索しているこ とに相当する.

隣接関係の切断とは, 隣接ロボットを一時的に隣接ロボット でないとみなすことを意味する。このプロセスはあるロボット が停留していると判断したときに行われる，停留はドロネー生 成周期内に進んだ距離により判断する。

Fig. 8 (a) は安定な群れが狭領域に突入したときの群れの一 部の様子であり，破線は黒丸の Follower が生成するドロネ一線 罒を表している。この Follower が停留を検知し，×印で表され る隣接関係を切断すると, 群れは Fig. 8(b)のように動き, 構 造遷移が起きる. 最終的に Fig. 8 (c) のように, 切断前よりも 群れ全体がロボット 1 台分進行する.

どの隣接ロボットを切断すれば構造遷移が起きるかは周囲の 隣接関係に依存するため, 局所的に判断することはできない. そのため切断は, 切断しても群れを維持できると推定される隣 接ロボットの中からランダムに 1 台選んで行う。切断した隣接 ロボットとの距離が $S$ 以上離れてしまった場合や, 切断後一定 時間たっても構造遷移が起きず停留が回避されない場合, 切断 は不適切であったとみなし, 切断を中止する. 切断の判定周期 は，ドロネー生成周期の定数倍とする.

切断とそれに伴う構造遷移を繰り返すことにより，狭領域入 り口近傍での群れの構造は Fig. 9 の状態遷移図のように確率 的に変化していく. 状態遷移図において, 実線の矢印は自分が 切断を行った場合, 破線の矢印は他のロボットが自分との隣接 関係を切断した場合に状態が遷移する可能性があることを示す。 これにより，無限時間経過後は確実に群れが通過することがで きる。ただ，通過に要する期待時間はロボット台数の増大に より増加する．また，初期状態で群れの内側に障害物を巻き込 む状態であった場合, 停留回避に要するランダム探索の量が多 くなり，長い時間を要する可能性がある。

\section{4. 提案手法の検証}

4.1 全方向移動ロボットによるシミュレーション 提案手法による群れ構造遷移の有効性をシミュレーションによ り示す. 作業条件として, リーダーが 9 台のフォロワを引き連れ 


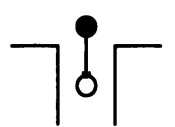

$1-8$

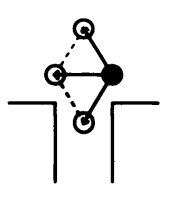

3-a

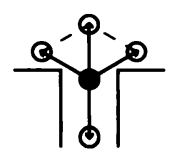

4-b

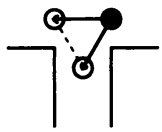

2-a
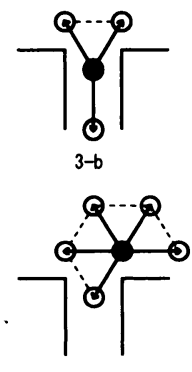

5-a
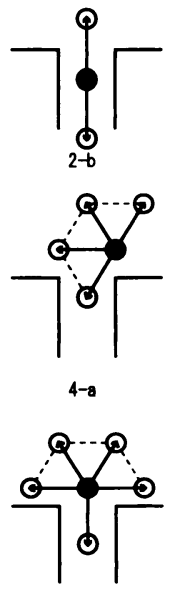

$5-b$ (a) Possible status

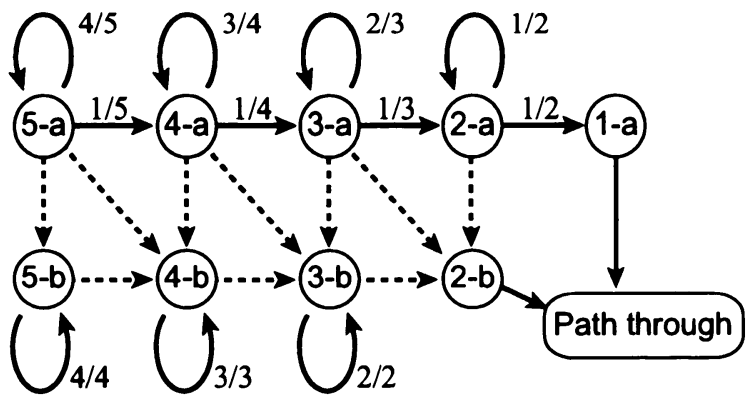

(b) State-transition map

Fig. 9 Transitions at deadlocks

て移動することを設定した．ロボット半径 $R=0.3, \tau_{L}=30$, $\tau_{H}=150, \delta=300, D=1, V=5.0, S=4.0$, サンプリン グ周期 $0.001[\mathrm{~s}]$, ドロネー生成周期 $0.1[\mathrm{~s}]$, 切断判定周期 $1.0[\mathrm{~s}]$ とした。

Fig. 10 に, 幅 1.5 の狭領域通過のシミュレーション結果を 示す. 適当な初期状態に配置されたフォロワは，自律的に安定 な群れを形成する (Fig. $10(2))$ 。リーダーが狭領域を通過し ようとすると, 安定な群れを形成しているために停留が起こる

(Fig. $10(3)$ ). 停留を検知したフォロワは隣接ロボットを切断し, 構造遷移が起こる (Fig. 10(4))。これを繰り返し, 最終的に群れ は進行しやすい群れとなって狭領域を通り抜ける（Fig. 10(5)). 通過後は再び安定な群れに復帰する（Fig. $10(6))$.

Fig. 11 に，相対的に複雑な環境下におけるシミュレーショ ン結果を示す。この環境では，ロボット 1 台分の幅しかない部 分, ロボット 2 台分の幅がある部分, それ以上の広さがある自 由空間が環境の部分空間として混在するが, 群れは環境に応じ て適宜構造遷移を起こし，障害物領域の通過を可能としている.

以上のシミュレーションより, 全方向移動ロボットの群れに 対し, 提案手法が環境に適応した群れ構造遷移を行ったうえで 狭領域の通過を可能としていることが示された.

\subsection{2 輪車ロボットへの適用}

提案手法を 4 台の 2 輪車ロボットに適用する検証実験を行っ た.用いた 2 輪車のモデルを Fig. 12 に示す．制御入力は両車 輪の回転速度である.用いた 2 輪車はノンホロノミック拘束を

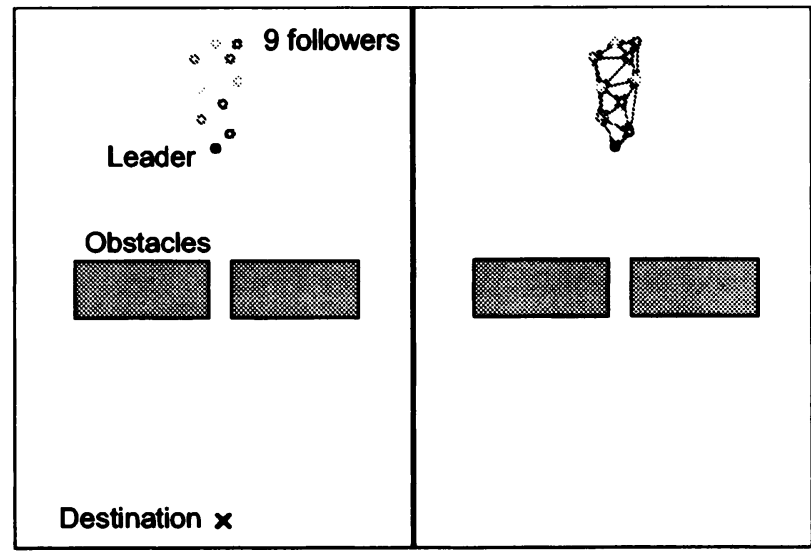

(1)

(2)

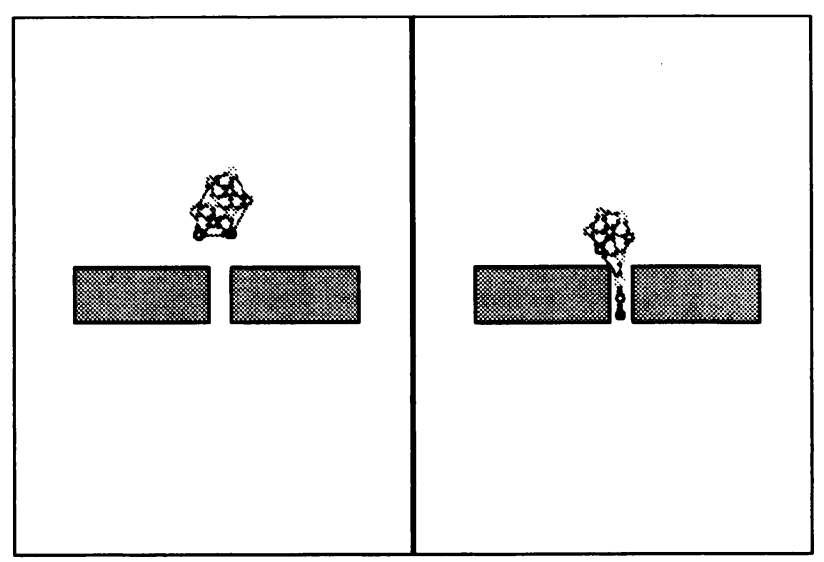

(3)

(4)

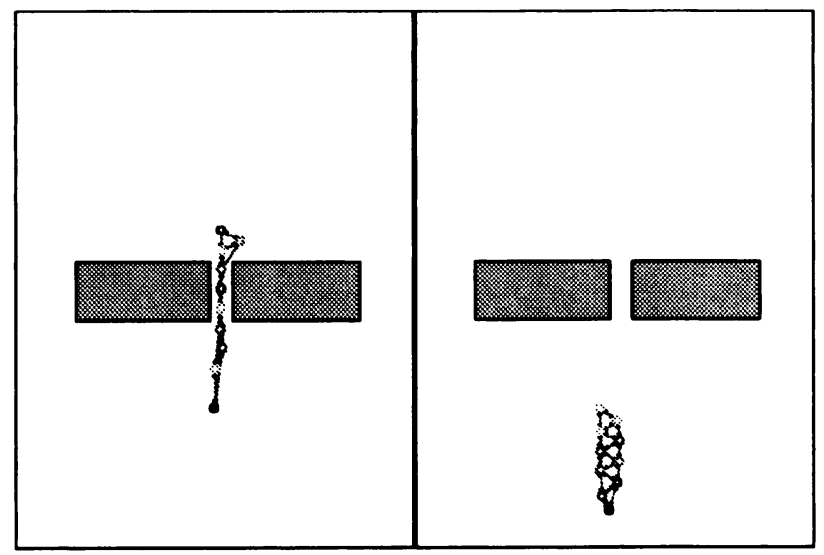

(5)

(6)

Fig. 10 Passing through a narrow corridor

受けるが，図中のように制御点を 2 輪車の車軸中心から $L$ だけ 前方にずらし，制御点を中心として 2 輪車が完全に入るような 円形の仮想ロボットを考え, 制御点の速度成分を（2）から決定 したうえで車輪回転速度を求める [14]こととした。

$$
\left[\begin{array}{c}
w_{\text {right }} \\
w_{\text {left }}
\end{array}\right]=\left[\begin{array}{cc}
\frac{1}{r_{t}} & \frac{r_{a}}{r_{t}} \\
\frac{1}{r_{t}} & -\frac{r_{a}}{r_{t}}
\end{array}\right]\left[\begin{array}{cc}
\cos \theta & \sin \theta \\
-\frac{\sin \theta}{L} & \frac{\cos \theta}{L}
\end{array}\right]{ }^{i} \dot{\boldsymbol{x}}_{i}
$$




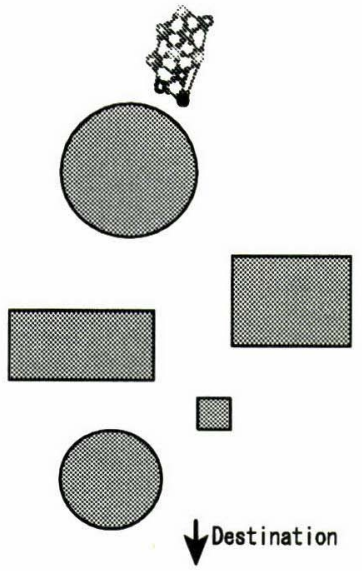

(1)

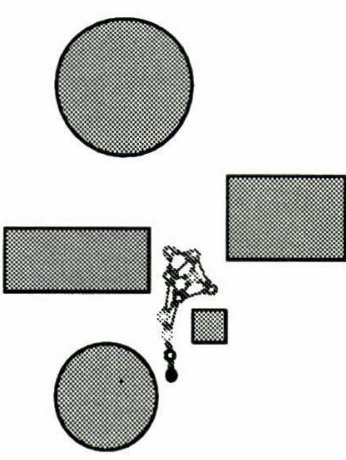

(3)

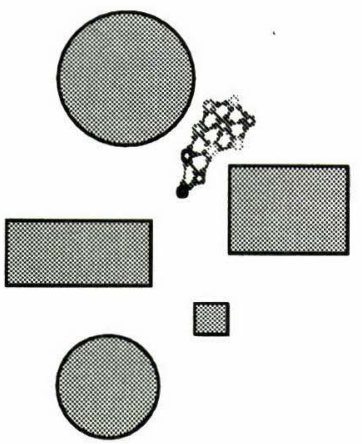

(2)
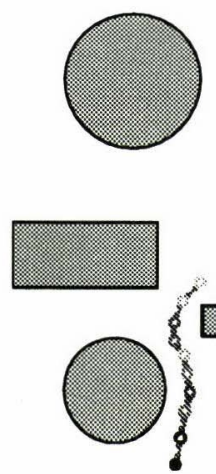

(4)
Fig. 11. Formation transitions according to the environment

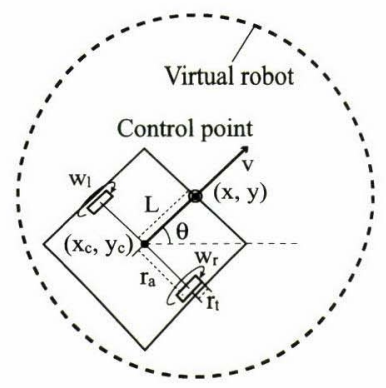

Fig. 12 A two-wheeled robot

実験は天井に取り付けられたカメラからロボットと障害物の位 置, 姿勢を読み取り，ホストコンピュータで必要な情報の計算を 行い, 無線機で各ロボットへ送ることにより行った。仮想ロボット の半径 $R=0.1[\mathrm{~m}], \tau_{L}=30, \tau_{H}=60, \delta=2, D=0.15[\mathrm{~m}]$, $V=1.2[\mathrm{~m}], S=0.8[\mathrm{~m}]$ とした。サンプリング周期 $0.2[\mathrm{~s}]$, ドロネー生成周期 $2.0[\mathrm{~s}]$, 切断の判定周期 $2.0[\mathrm{~s}]$ と設定した。

シミュレーションでは個々のロボットによる分散的な処理を 仮定しており，また実験に用いたロボット（ロボカップ・小型機 リーグ用）は，それぞれに複数の赤外線センサを搭載している が, 相手の弁別や相対位置の把握に性能が十分でないため, セン サを模擬するものとして天井のカメラを用いるものとした。こ の点については, 相互并別が可能な赤外・超音波複合センサシ ステム（Araiらの LOCISS [15] など）を利用することで, 個々

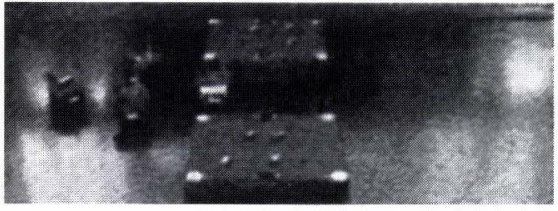

(1)

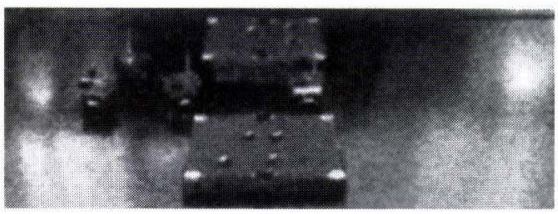

(2)

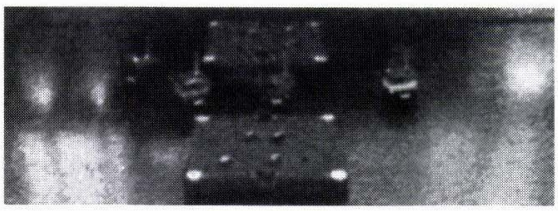

(3)

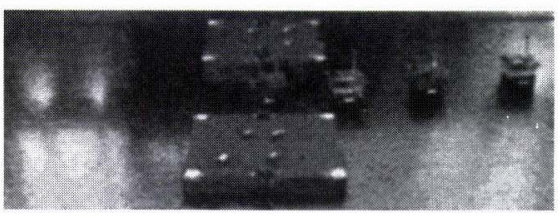

(4)

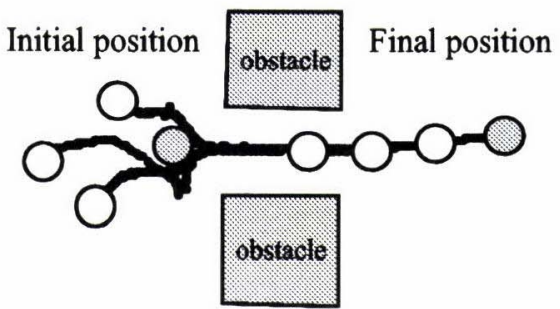

(5) Recorded trajectories

Fig. 13 An experiment with four two-wheeled robots

のロボットによる完全な自律動作が可能であると考える.

実験では, 計測䛊差に対する群れ構造遷移の動作, 2 輪車両へ の応用について検討した，2 輪車ロボットを用いた狭領域通過 実験の結果をFig. 13 に示す.実験においてもシミュレーショ ン同様に編隊形成および狭領域通過が達成されている。またシ ミュレーションと異なり，画像認識誤差によりロボット間相対 位置が摂動したり，各ロボットごとの動作にズレが生じるなと の現象が見られるが，ロボット群は群れの連結を失うことなく， 所期の挙動を得ることができた。

$$
\text { 5.おわりに }
$$

本研究では，障害物空間に掞ける自律移動ロボット群の群れ 移動アルゴリズムを構築した. 1 台のリーダーロボットが複数 のフォロワロボットを目的地に連れて行くというタスクに対し， 各ロボットが自律的に環境に応じて群れの構造を変化させ, 群 れの形成，維持，および停留の回避を実現するアルゴリズムを 提案した，そして全方向移動ロボットでのシミュレーション, 2 
長 川研 太

輪車ロボットでの実験を行い, その有効性を確認した。

謝 辞 本研究の一部は, 科学研究費補助金·基盤研究 (B)

(2) 14350117 の補助により行われた.

\section{参 考 文 献}

[1] L.E. Buzogany, M. Pachter and J.J. D'Azzo: "Automated control of aircraft in formation flight," AIAA Guidance, Navigation and Control Conf., Part 3, pp.1349-1370, 1993.

[2] V.P. Reyna, M. Pachter and J.J. D'Azzo: Formation flight control automation, AIAA Guidance Navigation, and Control Conf., Part 3, pp.1379-1404, 1994

[ 3 ] A.W. Proud, M. Pachter and J.J. D'Azzo: "Close formation flight control," AIAA Guidance, Navigation and Control Conf., vol.2, pp.1231-1246, 1999

[4] S.N. Singh: "Adaptive feedback linearization nonlinear close formation control of UAVs," Proc. Americal Control Conf., pp. 854-858, 2000.

[5] 太田順, 新井民夫: “群秩序生成可能な追従戦略を用いた複数移動ロボッ ト系の動作計画”, 日本ロボット学会誌, vol.12, no.4, pp.603-608, 1994.

[6] 太田順, 新井民夫, 倉林大輔：“作業の性質を考慮したロボット群の 動作計画”, 日本ロボット学会誌, vol.13, no.4, pp.517-524, 1995.

[ 7] ジョンユースック・ジュラチャート, 美多勉, 山北昌毅：“切り替え型 制御による衝突回避を考虑した複数編隊無人飛行機の形成制御”, シ ステム制御情報学会論文誌, vol.17, no.1, pp.26-38, 2004.
[8] J.E. Hopcroft, J.T. Schwartz and M. Sharir: "On the Complexity of Motion Planning for Multiple Independent Objects; P-SPACE Hardness of the Warehouseman's Problem," Int. J. Robotics Res., vol.3, no.4, pp.76-88, 1984.

[9] J.P. Desai, J.P. Ostrowski and V. Kumar: "Modeling and Control of Formation of Nonholonomic Mobile Robots," IEEE Trans. Robotics and Automation, vol.17, no.6, pp.905-908, 2001.

[10] M. Shimizu, A. Ishiguro, T. Kawakatsu, Y. Masubuchi and M. Doi: "Coherent Swarming from Local Interaction by Exploiting Molecular Dynamics and Stokesian Dynamics Methods," Proc. Int. Conf. Intelligent Robots and Systems, pp.1604-1619,2003.

[11] H. Yamaguchi: "A Cooperative Hunting Behavior by Mobile Robot Troops," Proc. Int. Conf. Robotics and Automation, pp.3204-3209, 1998.

[12] J.A. Bondy and U.S.R. Murty: グラフ理論への入門. 共立出版, 1991.

[13] M. ドバーグ, M. ファン. クリベルド, 他：コンピュータ・ジオメト リ. 近代科学社, 2000

[14] 美多勉：非線形制御入門．昭晃堂，2000。

[15] Y. Arai, S. Suzuki, K. Kotosaka, H. Hajime, H. Kaetsu and I. Endo: "Collision Avoidcance among Multiple Autonomous Mobile Robots using LOCISS (LOcally Communicable Infrared Sensory System)," Proc. IEEE Int. Conf. Robotics and Automation, pp.2091-2096, 1996.

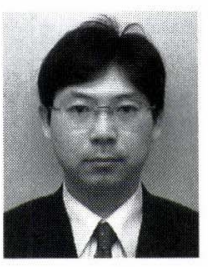

倉林大輔（Daisuke Kurabayashi）

1970 年 9 月 15 日生. 1998 年東京大学大学院工学 系研究科博士課程修了. 同年理化学研究所基礎科学 特別研究員. 2001 年東京工業大学大学院講師を経 て 2003 年同助教授. マルチエージェントシステム の機能創発に興味を持つ。博士 (工学)。日本機械 学会, 計測自動制御学会, 精密工学会, IEEE 等の 会員.

(日本ロボット学会正会員)

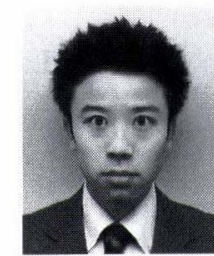

長川研太 (Kenta Osagawa)

1979 年 4 月 7 日生. 2004 年東京工業大学大学院 理工学研究科修士課程修了. 同年，パイオニア株式 会社入社.カーナビゲーションシステムの位置認識 に関する研究・開発に従事. 修士 (工学). 